\title{
The China
} Quarterly

LIN ZHU on the punishment of corrupt officials

QIUQING TAI AND RORY TRUEX on attitudes to return migration

PETER LorentZEN AND

SuZANNE SCOgGIns on rising rights consciousness

JOHN K. YASUDA on food safety in China

BEIBEI TANG on community governance in urbanized villages 


\section{The China Quarterly}

Published by Cambridge University Press for SOAS, University of London.

The Editorial office

SOAS, Thornhaugh Street,

Russell Square, London WC1H 0XG.

Tel. $+44(0) 2078984063$

Fax +44(0)207898 4849

Email: chinaq@soas.ac.uk

\section{Subscriptions}

The China Quarterly (ISSN 0305-7410) is published quarterly in March, June, September and December by Cambridge University Press, University Printing House, Shaftesbury Road, Cambridge CB2 8BS, UK/Cambridge University Press, 32 Avenue of the Americas, New York, NY 10013-2473. The subscription price which includes electronic access and delivery by air where appropriate (but excluding VAT) of volumes 221 to 224 in 2015 is $£ 199.00$ (US $\$ 334.00$ in USA, Canada and Mexico) for institutions; $£ 44.00$ (US \$76.00) for individuals ordering direct from the publishers and certifying that the journal is for their personal use. Students can subscribe at $£ 20$ (US \$35). Single parts are $£ 53.00$ net (US $\$ 90.00$ in USA, Canada and Mexico) plus postage. EU subscribers (outside the UK) who are not registered for VAT should add VAT at their country's rate. VAT registered members should provide their VAT registration number. Japanese prices for institutions (including ASP delivery) are available from Kinokuniya Company Ltd, P.O. Box 55, Chitose, Tokyo 156, Japan.

Orders, which must be accompanied by payment, may be sent to a bookseller, subscription agent or direct to the publisher: Cambridge University Press, University Printing House, Shaftesbury Road, Cambridge CB2 8BS, UK. or in the USA, Canada and Mexico: Cambridge University Press, 32 Avenue of the Americas, New York, NY 100132473. Periodical postage paid at New York, NY and additional mailing offices. POSTMASTER: Send address changes to Cambridge University Press, 32 Avenue of the Americas, New York,

NY 10013-2473.

The current plus three back volumes are available from Cambridge University Press.

\begin{abstract}
Advertising
Advertisements are welcomed and rates will be quoted on request. Enquiries should be addressed to Advertising Promoter, Journals Group, Cambridge University Press, The Edinburgh Building, Shaftesbury Road, Cambridge CB2 8RU, UK. Tel +44 (0)1223 $325757 \mathrm{Fax}+44(0) 1223325801$.
\end{abstract}

\section{Copying}

This journal is registered with the Copyright Clearance Center, 222 Rosewood Drive, Danvers, MA 01923, USA. Organizations in the USA who are also registered with the C.C.C. may, therefore, copy material (beyond the limits permitted by sections 107 and 108 of U.S. Copyright law) subject to payment to the C.C.C of the per copy fee of $\$ 12.00$. This consent does not extend to multiple copying for promotional or commercial purposes. Code 0305-7410/14. ISI Tear Sheet Service, 3501 Market Street, Philadelphia, PA 19104, USA, is authorized to supply single copies of separate articles for private use only. Organizations authorized by the Copyright Licensing Agency may also copy material subject to the usual conditions. For all other use, permission should be sought from Cambridge or from the American Branch of Cambridge University Press.

This journal is included in the Cambridge Journals Online Service which can be found at journals.cambridge.org. For further information on other Press titles access journals.cambridge.org.

(C) The China Quarterly, 2015 ISSN 0305-7410

Typeset by Techset Composition Ltd, Salisbury, UK. Printed in the United Kingdom by Bell \& Bain, Glasgow

This journal issue has been printed on $\mathrm{FSC}^{\mathrm{TM}}$-certified paper and cover board. FSC is an independent, non-governmental, not-for-profit organization established to promote the responsible management of the world's forests. Please see www.fsc.org for information. 


\section{The China Quarterly \\ an international journal for the study of China}

\section{September 2015 number 223}

\section{Articles}

595 Punishing Corrupt Officials in China

Lin Zhu

618 Pernicious Manipulation of Performance Measures in China's Cadre Evaluation System

Jie Gao

638 Understanding China's Rising Rights Consciousness

Peter Lorentzen and Suzanne Scoggins

658 Managing Political Opposition Groups in China: Explaining the Continuing

Anti-Falun Gong Campaign

Stephen Noakes and Caylan Ford

680 "The Power of the Purse" of Local People's Congresses in China: Controllable Contestation under Bureaucratic Negotiation

Jun Ma and Muhua Lin

702 Shall We Dance? Welfarist Incorporation and the Politics of State-Labour NGO

Relations

Jude Howell

724 "Not Rural but Not Urban": Community Governance in China's Urban Villages Beibei Tang

745 Why Food Safety Fails in China: The Politics of Scale John Kojiro Yasuda

770 Public Opinion towards Return Migration: A Survey Experiment of Chinese Netizens Qiuqing Tai and Rory Truex

787 Unifying the Ancestral Land: The CCP's "Taiwan" Frames Anne-Marie Brady

\section{Review Essay}

807 Is a Non-Capitalist World Possible?

China and Global Capitalism: Reflections on Marxism, History and Contemporary

Politics. By Lin Chun. Mobo Gao

Book Reviews

814 China's Political Development: Chinese and American Perspectives. Edited by Kenneth Lieberthal, Cheng Li and Yu Keping. Bruce Dickson

815 China's Futures: PRC Elites Debate Economics, Politics, and Foreign Policy. By Daniel C. Lynch. Bruce Gilley

816 China Goes Global: The Partial Power. By David Shambaugh. Jae Ho Chung

818 China and the United Nations: Chinese UN Policy in the Areas of Peace and Development in the Era of Hu Jintao. By Janka Oertel. Courtney J. Fung

820 The China-Pakistan Axis: Asia's New Geopolitics. By Andrew Small. Edward Friedman 
822 The China Problem in Postwar Japan: Japanese National Identity and Sino-Japanese Relations. By Robert Hoppens. Reinhard Drifte

823 The Growth of Chinese Electronics Firms: Globalization and Organizations. By Koichiro Kimura. Albert G. Hu

825 Class and Class Conflict in Post-Socialist China. By Alvin Y. So. Chris King-Chi Chan

826 China's Human Rights Lawyers: Advocacy and Resistance. By Eva Pils. Katrin Kinzelbach

828 The Judicial System and Reform in Post-Mao China: Stumbling Towards Justice. By Yuwen Li; Administrative Litigation Systems in Greater China and Europe. Edited by Yuwen Li. Mimi Ajibadé

830 Children, Rights, and Modernity in China: Raising Self-Governing Citizens. By Orna Naftali. Xuan Li

832 Subaltern China: Rural Migrants, Media, and Cultural Practices. By Wanning Sun. Lisa Rofel

834 Family Revolution: Marital Strife in Contemporary Chinese Literature and Visual Culture. By Hui Faye Xiao; Popular Media, Social Emotion and Public Discourse in Contemporary China. By Shuyu Kong. Chris Berry

835 The Impotence Epidemic: Men's Medicine and Sexual Desire in Contemporary China. By Everett Yuehong Zhang. Kam Louie

837 Shanghai Homes: Palimpsests of Private Life. By Jie Li. Jeffrey Wasserstrom

839 A Landscape of Travel: The Work of Tourism in Rural Ethnic China. By Jenny Chio. John A. Donaldson

840 The Political Economy of News in China: Manufacturing Harmony. By Jesse Owen Hearns-Branaman. Judy Polumbaum

842 Media Transparency in China: Rethinking Rhetoric and Reality. By Baohui Xie. David Ryfe

844 Tiananmen Fictions outside the Square: The Chinese Literary Diaspora and the Politics of Global Culture. By Belinda Kong. Sebastian Veg

846 Verse Going Viral: China's New Media Scenes. By Heather Inwood. Géraldine Fiss

848 Visions of Dystopia in China's New Historical Novels. By Jeffrey C. Kinkley. Christopher N. Payne

850 Contemporary Chinese Art: A Critical History. By Paul Gladston. Xiaobing Tang

851 Van Gogh on Demand: China and the Ready Made. By Winnie Won Yin Wong. Gene Cooper

853 Neither Donkey Nor Horse: Medicine in the Struggle over China's Modernity. By Sean Hsiang-Lin Lei. Tina Phillips Johnson

855 The Making of Modern Chinese Medicine, 1850-1960. By Bridie Andrews. Francesca Bray

857 Books Received

\section{Notes on Contributors}

Please visit the journal's web site at www.cambridge.org and online at http://journals.cambridge.org/cqy

(C) SOAS, University of London, 2015

Typeset by Techset Composition Limited

Printed by Bell \& Bain, Glasgow, UK 


\section{The China Quarterly}

\section{Editor}

Chris Bramall
Editorial Managers

Raphael Jacquet

Rowan Pease
Editorial Assistant

Joanne Phillips

\section{Executive Committee}

Chris Berry, King's College London

Jane Duckett, University of Glasgow

Harriet Evans, University of Westminster

Dafydd Fell, SOAS, University of London

Enze Han, SOAS, University of London
Jude Howell, London School of Economics Chun Lin, London School of Economics

Rachel Murphy, University of Oxford

Tim Pringle, SOAS, University of London

Patricia M. Thornton, University of Oxford

\section{Editorial Board}

Joel Andreas, Johns Hopkins University

Yanjie Bian, University of Minnesota I

Xi'an Jiaotong University

Loren Brandt, University of Toronto

Donald C. Clarke, George Washington University Law School

Deborah Davis, Yale University

Joseph Fewsmith, Boston University

Vanessa Fong, Harvard Graduate School of Education

M. Taylor Fravel, Massachusetts Institute of Technology

Natascha Gentz, University of Edinburgh

Bates Gill, United States Studies Centre, University of Sydney

Peter Hays Gries, University of Oklahoma

Lei Guang, San Diego State University

Stevan Harrell, University of Washington

Thomas Heberer, University of Duisburg-Essen

Sebastian Heilmann, Mercator Institute for China Studies (MERICS), Berlin

Carsten Holz, Hong Kong University of Science and Technology
Ching Kwan Lee, University of California, Los Angeles

Li Shi, Beijing Normal University

Melanie Manion, University of Wisconsin, Madison

Françoise Mengin, CERI-Sciences Po, Paris

Andrew Mertha, Cornell University

Kevin O'Brien, University of California, Berkeley

Jean-Louis Rocca, CERI-Sciences Po, Paris

Lisa Rofel, University of California, Santa Cruz

Scott Rozelle, Stanford University

Gunter Schubert, Eberhard Karls

University Tübingen

Helen Siu, Yale University

Xiaobing Tang, University of Michigan

Stig Thøgersen, Aarhus Universitet

Teresa Wright, California State University, Long Beach

Guobin Yang, University of Pennsylvania

\section{Former Editors}

Roderick MacFarquhar (1960-68)

David C. Wilson [Lord Wilson of Tillyorn] (1968-74)

John Gittings (Acting Editor 1972)

Dick Wilson (1975-80)
Brian G. Hook (1980-91)

David Shambaugh (1991-96)

Richard Louis Edmonds (1996-2002)

Christopher B. Howe (Acting Editor 2005)

Julia Strauss (2002-11) 